Terbit online pada laman web jurnal : http://teknosi.fti.unand.ac.id/

Jurnal Nasional Teknologi dan Sistem Informasi

ISSN (Print) 2460-3465 | ISSN (Online) 2476-8812

"Artikel Penelitian"

\title{
Kebutuhan Perangkat Lunak Untuk Aplikasi Data Mining
}

\author{
Ibnu Surya \\ Politeknik Caltex Riau, Jl. Umban Sari No. 1, Pekanbaru, Indonesia
}

\begin{tabular}{|c|}
\hline INFORMASI ARTIKEL \\
\hline $\begin{array}{l}\text { Sejarah Artikel: } \\
\text { Diterima Redaksi: } 15 \text { Juli } 2017 \\
\text { Revisi Akhir: 02 September } 2017 \\
\text { Diterbitkan Online: } 31 \text { Agustus } 2017\end{array}$ \\
\hline KATA KUNCI \\
\hline $\begin{array}{l}\text { requirements } \\
\text { software } \\
\text { architecture } \\
\text { datamining } \\
\text { application }\end{array}$ \\
\hline KORESPONDENSI \\
\hline $\begin{array}{l}\text { Telepon: +62 } 85272673321 \\
\text { E-mail: ibnu@pcr.ac.id }\end{array}$ \\
\hline
\end{tabular}

\section{A $\quad$ B $\mathbf{S}$ T $\mathbf{R}$ A $\mathbf{C}$ T}

In software development, the software requirements are the result of understandings of user requirements or the system owners to the developer. Based on these requirements, the developers are able to develop their software architecture. Based on software architecture, developers can construct a set of requirements. This reuse process shall give positive impacts to a better software product. This research uses a technique for generating software requirements for data mining based on data mining software architecture, especially a data mining application for analyzing social media. The contribution of this research is a proposal of a generic data mining requirements software that is expected to be reference for data mining application development. The proposal is evaluated to three different data mining applications that each consists of four typical requirements. These three applications are compared to our generated requirements. The results show that $50 \%$ of our requirements have been used in these applications or an average of $83.33 \%$ requirements from our proposal has contributed to these three applications. It shows that the technique used to generate software requirements based on software architecture is able to provide an alternative to develop new common requirements.

\section{PENDAHULUAN}

Pengembangan perangkat lunak sebelumnya telah melihatkan hubungan antara kebutuhan dan arsitektur. Dimana kebutuhan yang diperoleh digunakan oleh arsitek perangkat lunak untuk mengembangkan suatu arsitektur yang memenuhi kebutuhan yang diharapkan. Hal ini cenderung mengarahkan terciptanya desain yang mempunyai inovasi yang baik dalam mengimplementasikan setiap sistem yang baru [1].

Tentunya peranan kebutuhan ini dapat memberikan pengaruh yang sangat penting untuk memberikan pemahaman kepada pemilik dan pengguna perangkat lunak ketika akan membangun suatu perangkat lunak. Penelitian sebelumnya telah menemukan persoalan kebutuhan dalam rekayasa perangkat lunak, satu diantaranya adalah kebutuhan yang dapat direalisasikan dengan lengkap hingga selesai yang menghasilkan produk perangkat lunak sekitar kurang dari 50\% kebutuhan [2]. Sehingga persoalan ini dapat menimbulkan masalah baru setelah perangkat lunak tersebut diimplementasikan. Seperti pelanggan mengasumsikan bahwasanya halaman webnya dapat ditampilkan dengan waktu loading kurang dari 2 detik, tetapi hasilnya tidak demikian bahkan terlalu lambat [3]. Persoalan ini merupakan bagian dari keinginan pengguna yang menjadi asumsi tapi tidak terdefinisi

https://doi.org/ 10.25077/TEKNOSI.v3i2.2017.233-240 dengan detil dan lengkap dalam suatu kebutuhan.

Untuk tujuan peningkatan dan pengembangan serta memberikan jawaban tentang permasalahan kebutuhan pengguna terhadap suatu perangkat lunak, tentunya menjadi sejalan dalam penelitian ini untuk lebih lanjut menganalisa arsitektur perangkat lunak sebelumnya dari kelompok keluarga perangkat lunak tertentu yang akan menjadi rujukan sehingga dapat berperan dalam praktik rekayasa kebutuhan dalam suatu pembangunan perangkat lunak.

\section{RESEARCH QUESTION}

Pemahaman awal dalam pengembangan arsitektur sistem perangkat lunak sebelumnya memberikan dasar untuk mendapatkan kebutuhan dan batasan-batasan yang dapat dievaluasi kelayakan teknisnya dari suatu sistem hingga menemukan solusi alternatif dalam permasalahan kebutuhan suatu perangkat lunak khususnya kebutuhan aplikasi datamining. Untuk itu yang menjadi kontribusi dan pertanyaan dalam penelitian ini apakah kebutuhan yang diperoleh berdasarkan arsitektur dapat memberikan pengaruh dengan peningkatan yang 
baik dalam menyelesaikan persoalan kebutuhan perangkat lunak pada kebutuhan aplikasi datamining ?

\section{TINJAUAN PUSTAKA}

Untuk mendukung dalam penelitian ini, akan merujuk beberapa penelitian sebagai referensi.

\subsection{Rekayasa Kebutuhan}

Rekayasa kebutuhan fokus menentukan dimensi persoalan atau domain permasalahan yang akan diselesaikan dengan sistem perangkat lunak [1]. Pendapat lainnya diakui juga bahwasanya rekayasa kebutuhan mempuyai tugas yang penting, karena kegagalan perangkat lunak banyak disebabkan oleh ketidak konsistenan, ketidak lengkapan bahkan spesifikasi kebutuhan yang tidak benar [4]. Sebelumnya penelitian dalam rekayasa kebutuhan banyak diarahkan kepada bagaimana perangkat lunak itu dibangun sesuai dengan kebutuhan pemilik dan pengguna perangkat lunak yang merupakan dasar dari perangkat lunak itu akan dibangun [5].

\subsection{Arsitektur Perangkat Lunak}

Arsitektur perangkat lunak merupakan struktur sebuah sistem, yang meliputi komponen-komponen dari unit perangkat lunak, sifat (property) yang tampak dari komponen tersebut, serta relasi diantara komponen tersebut. Sifat yang tampak misalnya fungsi apa saja yang disediakan oleh komponen, bagaimana kinerjanya, bagaimana kesalahannya, sumber daya apa saja yang digunakan [6].

\subsection{Mendapatkan kebutuhan Arsitektur}

Untuk mendapatkan kebutuhan dari desain model arsitektur dapat diperoleh dari deskripsi komponen. Dimana setiap kendala yang muncul dari komponen akan menjadi batasan dari subsistem. Komponen merupakan bagian sistem dari sistem keseluruhannya, sehingga Kebutuhan yang dihasilkan harus mengatasi fungsionalitas yang mesti tersedia oleh komponen [7].

\subsection{Data mining}

Dalam buku (Oracle Data Mining Concepts 2008), memberikan gambaran data mining adalah praktik yang secara otomatis mencari data dalam repositori yang besar untuk menemukan pola dan tren yang melebihi analisis yang sederhana. Dengan menggunakan pendekatan algoritma yang kompleks untuk segmen data tertentu dan mengevaluasi kemungkinan terjadi dimasa depan [8].

Data mining dapat mempercepat analisis dengan memfokuskan perhatian terhadap variabel yang paling penting. Dengan kemampuan sistem komputer yang semakin cepat, sekarang banyak organisasi-organisasi untuk memulai menerapkan aplikasi datamining. Setiap aplikasi data mining biasanya didukung dengan sekumpulan algoritma untuk mengambil relasi dalam data. Alasan utama data mining pada industri adalah, data yang tersedia dalam jumlah yang sangat besar dan semakin bertambah besarnya kebutuhan untuk mengubah data tersebut menjadi informasi dan pengetahuan yang lebih bermanfaat.

\subsection{Datamining pada media sosial}

Melakukan mining pada web sosial adalah cara menemukan siapa yang terhubung dengan siapa, apa yang sedang mereka bicarakan atau dimana lokasi mereka berada. Mining sosial web adalah bagian dari cara untuk memperoleh data, menganalisis dan menyimpulkan data tersebut [9].

234 Ibnu Surya

\section{HASIL DAN PEMBAHASAN}

Proses yang dilakukan pada bagian ini adalah bagaimana mendapatkan kebutuhan yang penting dari arsitektur perangkat lunak. Kebutuhan arsitektur diperoleh dari arsitektur perangkat sebelumnya untuk analisis data media sosial. Dari percobaan ini, kebutuhan yang diperoleh dari arsitektur perangkat lunak tersebut akan digunakan untuk kasus aplikasi data mining.

4.1. Bagaimana mendapatkan kebutuhan dari arsitektur Untuk mendapatkan kebutuhan berdasarkan arsitektur, sistematika proses yang dilakukan adalah sebagai berikut,

1. Menganalisa kebutuhan arsitektur perangkat lunak versi sebelumnya milik Anggi Perwitasari [9]. Dan Arsitektur perangkat lunak sebelumnya akan digunakan dalam mendapatkan pengetahuan dari arsitektur, untuk digunakan sebagai pertimbangan melihat unit dari arsitektur yang cenderung berubah kedepannya.

2. Kebutuhan akan diturunkan dengan menggunakan template user stories untuk melihat kebutuhan pengguna dari deskripsi kebutuhan arsitektur sebelumnya.

3. Selanjutnya mengidentifikasi kebutuhan yang penting. Dengan menerapkan kerangka yang sudah ada sebagai panduan dalam mengelompokkan karakteristik kebutuhan arsitektur, apakah merupakan kebutuhan yang penting atau tidak.

\subsection{Arsitektur perangkat lunak pada penelitian} sebelumnya

Pada penelitian ini dilakukan proses evaluasi terhadap arsitektur perangkat lunak aplikasi data mining pada data media sosial, sehingga dalam pengembangan yang dihasilkan tersebut akan dikelompokkan dalam beberapa kebutuhan yang penting. Kedepannya kebutuhan yang diperoleh akan digunakan untuk dilakukan pengujian pada kebutuhan aplikasi data mining lainnya, apakah kebutuhan yang diperoleh dapat memberikan gambaran dan pengetahuan awal bagi pemilik dan pengguna perangkat lunak yang mengembangkan aplikasi data mining.

Arsitektur perangkat lunak yang digunakan ditampilkan sebagai berikut,

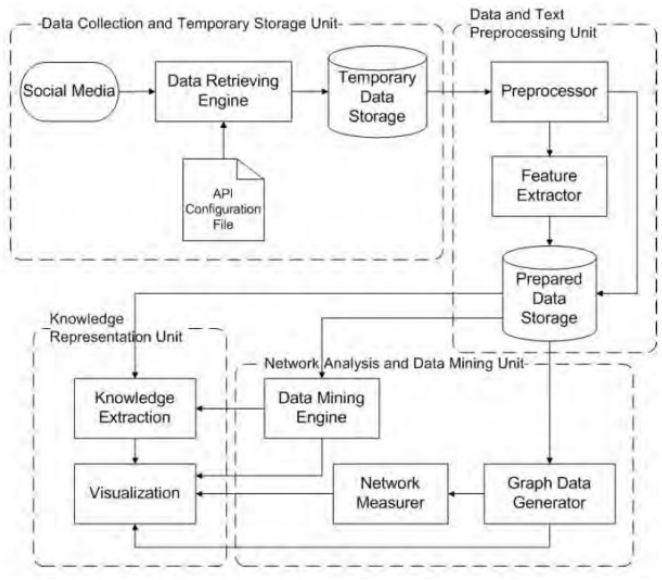

Gambar 1 Arsitektur Perangkat Lunak

(Sumber: Perwitasari, 2015)

https://doi.org/ 10.25077/TEKNOSI.v3i2.2017.233-240 
Kebutuhan pengguna dari arsitektur sistem perangkat lunak yang dikembangkan dari penelitian sebelumnya didetilkan dalam template format Cohn, sebagai berikut .

Tabel 1. User Stories

\begin{tabular}{|c|c|c|}
\hline No & Kriteria & Keterangan \\
\hline \multirow[t]{13}{*}{1} & \multirow{13}{*}{$\begin{array}{l}\text { Berperan sebagai } \\
\text { apa } \\
(A s a)\end{array}$} & \multirow{13}{*}{$\begin{array}{l}\text { Muhammad Mahbubur } \\
\text { Rahman, } \\
\text { Bekerja sebagai Asisten Profesor } \\
\text { di Departemen Komputer Sains } \\
\text { American International } \\
\text { Universitas-Bangladesh. Minat } \\
\text { penelitiannya diantaranya adalah } \\
\text { pada Data Mining, Machine } \\
\text { Learning, Bioinformatika, Game } \\
\text { Theory dan Artificial Intelligence. } \\
\text { Saat ini penelitian yang aktif dalam } \\
\text { bidang bioinformatika dan data } \\
\text { mining. Mempunyai beberapa } \\
\text { tahun pengalaman bekerja di } \\
\text { perusahaan telekomunikasi dan } \\
\text { perangkat lunak lokal dan } \\
\text { internasional. }\end{array}$} \\
\hline & & \\
\hline & & \\
\hline & & \\
\hline & & \\
\hline & & \\
\hline & & \\
\hline & & \\
\hline & & \\
\hline & & \\
\hline & & \\
\hline & & \\
\hline & & \\
\hline \multirow[t]{18}{*}{2} & \multirow[t]{18}{*}{$\begin{array}{l}\text { Yang diinginkan } \\
\text { (I Want) }\end{array}$} & $\begin{array}{l}\text { Berikut kebutuhan pada Collecting } \\
\text { Data. }\end{array}$ \\
\hline & & \multirow{7}{*}{$\begin{array}{l}\text { 1. Data retrieving engine dapat } \\
\text { melakukan koneksi secara } \\
\text { langsung yang terhubung } \\
\text { dengan server Facebook } \\
\text { dengan bantuan API Key dan } \\
\text { Application Secret yang } \\
\text { diciptakan melalui facebook } \\
\text { dan digunakan untuk } \\
\text { mengakses (log-in) akun }\end{array}$} \\
\hline & & \\
\hline & & \\
\hline & & \\
\hline & & \\
\hline & & \\
\hline & & \\
\hline & & facebook. Data retrieving \\
\hline & & engine digunakan untuk \\
\hline & & mengumpulkan informasi \\
\hline & & (koleksi data) yaitu: about me, \\
\hline & & $\begin{array}{l}\text { wall, age, gender, comments. } \\
\text { Data tersebut disimpan }\end{array}$ \\
\hline & & kedalam temporary data \\
\hline & & storage. \\
\hline & & 2. Data retrieving \\
\hline & & dikembangkan \\
\hline & & menggunakan \\
\hline
\end{tabular}

pemrograman PHP dan $\mathrm{Web}$ Server Apache

3. Temporary data storage didesain dengan menggunakan MySQL DataBases Server

Kebutuhan pada Preprocessing Data,

4. Dapat mengubah data yang telah dikumpulkan ke dalam bentuk data transformasi yang nantinya digunakan oleh data parsing and classifying unit.

5. Transformed data storage juga menggunakan MYSQL database

Kebutuhan pada Data mining,

6. Parser yang digunakan untuk mengoleksi data dari Transformed Data Storage dan melakukan preprocessing data teks, dengan membuang kata yang bersifat umum, memperoleh kata kunci serta melakukan penciptaan, seleksi fitur dengan term frequency.

Kebutuhan pada Information

Extraction,

7. Knowledge extraction, mengekstraksi pengetahuan dengan melakukan komparasi hasil klasifikasi dengan data konkret media sosial dan memvisualisasikan datanya untuk memberikan pemahaman kepada pengguna.

(Sumber: Rahman, 2012)

Proses dari aplikasi data mining pada media sosial dari gambar 1 arsitektur diatas selanjutnya untuk mendapatkan kebutuhan diturunkan pada template user stories pada tabel 2 berikut,

Tabel 2.User Stories

\begin{tabular}{|c|c|c|}
\hline No & Kriteria & Keterangan \\
\hline 1 & $\begin{array}{l}\text { Berperan sebagai apa } \\
(A s a)\end{array}$ & $\begin{array}{l}\text { Anggi Perwitasari, } \\
\text { Mahasiswa S2 ITB di Jurusan Informatika dengan opsi pilihan Rekayasa } \\
\text { Perangkat Lunak. Penelitiannya saat ini diarahkan kepada } \\
\text { "pengembangan arsitektur perangkat lunak untuk analisis data media } \\
\text { sosial". }\end{array}$ \\
\hline 2 & $\begin{array}{l}\text { Yang diinginkan } \\
\text { (I Want) }\end{array}$ & $\begin{array}{l}\text { Berikut kebutuhan pada Collecting Data, } \\
\text { 1. Dapat melakukan koleksi data dari berbagai jenis media dengan proses } \\
\text { Log-in akses API terhadap tiga konten media sosial yang bersifat } \\
\text { publik yaitu informasi profil (umumnya } i d \text {, username, nama, dan }\end{array}$ \\
\hline
\end{tabular}


informasi lainnya), daftar kontak (id, username milik teman) dan kiriman pengguna berupa teks atau komentar yang dihasilkan dalam bentuk data terstruktur untuk mendukung proses penyimpanan dan proses data mining.

Kebutuhan pada Preprocessing Data,

2. Dapat melakukan berbagai teknik preprocessing data terstruktur untuk keperluan proses data mining pada media sosial (classification, clustering) maupun tidak terstruktur (membuat token, term) untuk mendukung proses data mining dan analisis dalam memperoleh pengetahuan

Kebutuhan pada Data Mining,

3. Dapat melakukan proses data mining (classification, clustering) dengan konten media sosial yang diperoleh untuk menemukan pengetahuan

Kebutuhan pada Graph Measuring,

4. Dapat melakukan analisis menggunakan data relasi dengan teknik pengukuran (network metrics) pada data relasi (main user dan friend) untuk memperoleh pengetahuan (influence, important)

\section{Kebutuhan pada Text Mining,}

5. Perangkat lunak dapat melakukan proses text mining media sosial pada data hasil pemrosesan data tekstual dari konten wall/ timeline media sosial untuk memperoleh berbagai pengetahuan (ex. Sentiment analysis, trending topic)

\section{Kebutuhan pada Information Extraction,}

6. Perangkat lunak dapat melakukan proses information extraction pada data media sosial untuk memperoleh informasi pada data konkret media sosial dan pengetahuan dari data tekstual

(Sumber: Perwitasari, 2015)

Kebutuhan dalam tabel 1 dan tabel 2 diatas menggambarkan kebutuhan pengguna.

Tabel 2. Pengelompokan kebutuhan arsitektur

\subsection{Kebutuhan arsitektur yang penting}

Berikut akan dilakukan pengelompokan kebutuhan yang penting dari kebutuhan sebelumnya sehingga dapat mengarahkan kebutuhan arsitektur perangkat lunak yang dapat mempengaruhi arsitektur.

\begin{tabular}{|c|c|c|c|c|}
\hline \multirow{2}{*}{$\begin{array}{r}\text { keputusan } \\
\text { User Stories (US) : }\end{array}$} & \multicolumn{2}{|c|}{ Kebutuhan Arsitektur } & \multirow{2}{*}{$\begin{array}{c}\text { M. M. } \\
\text { Rahman } \\
\checkmark\end{array}$} & \multirow{2}{*}{$\begin{array}{c}\begin{array}{c}\text { Anggi } \\
\text { Perwitasari }\end{array} \\
\checkmark\end{array}$} \\
\hline & US 1. & melakukan & & \\
\hline & & $\begin{array}{lrr}\text { koleksi data } & \text { dari } \\
\text { berbagai jenis } & \text { media } \\
\text { terhadap } & \text { konten } & \text { media } \\
\text { sosial } & & \end{array}$ & FB & $\begin{array}{l}\text { FB, Twiter, } \\
\text { Instagram }\end{array}$ \\
\hline & US 2. & $\begin{array}{l}\text { Data retrieving engine } \\
\text { dikembangkan dengan } \\
\text { menggunakan bahasa } \\
\text { pemrograman }\end{array}$ & $\begin{array}{c}\checkmark \\
\mathrm{PHP}\end{array}$ & $\begin{array}{c}\checkmark \\
\text { Object Pascal }\end{array}$ \\
\hline & US 3. & $\begin{array}{l}\text { Temporary data } \\
\text { storage didesain dengan } \\
\text { menggunakan DataBase } \\
\text { MySQL }\end{array}$ & $\begin{array}{c}\checkmark \\
\text { MySQL }\end{array}$ & $\begin{array}{c}\checkmark \\
\text { MySQL }\end{array}$ \\
\hline & US 4. & $\begin{array}{lr}\text { Dapat melakukan } \\
\text { berbagai } & \text { teknik } \\
\text { preprocessing } & \text { data } \\
\text { untuk keperluan proses } \\
\text { data mining }\end{array}$ & $\checkmark$ & $\checkmark$ \\
\hline
\end{tabular}




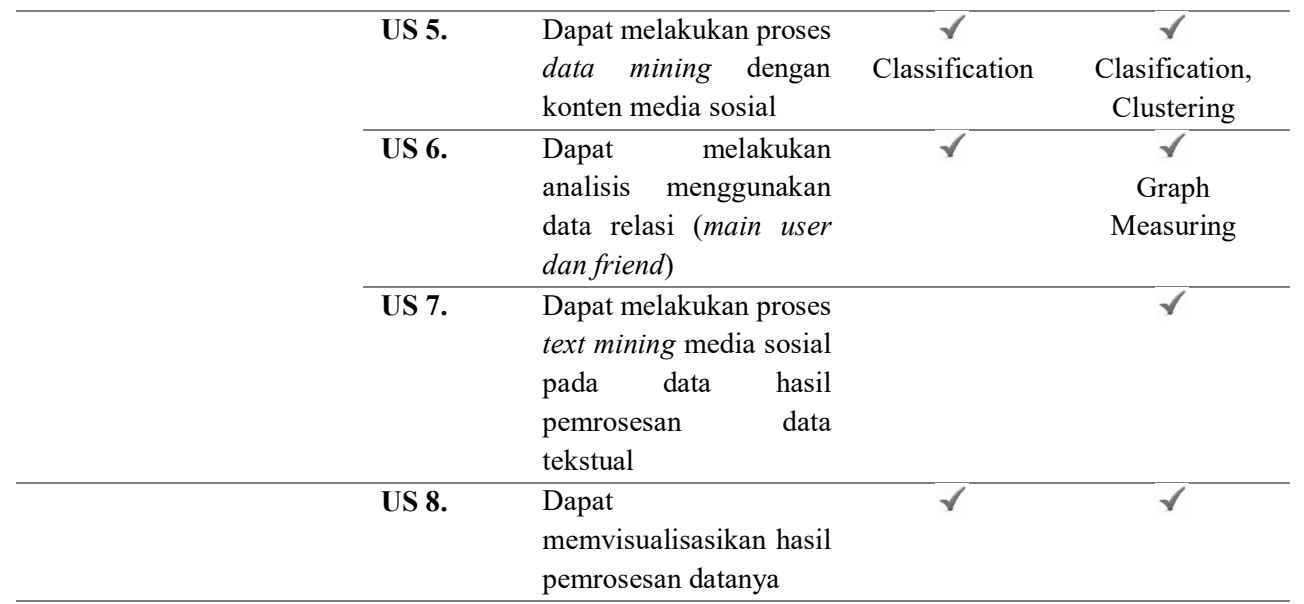

Kebutuhan Arsitektur yang akan berpengaruh terhadap Gaya Arsitektur (AD)
AD 1. Dapat melakukan koleksi data dari berbagai jenis media terhadap konten media sosial.

$\Rightarrow$ Perubahan yang mungkin berpengaruh pada arsitektur, diantaranya : adanya penambahan link terhadap konten pada media sosial dari kebutuhan pada versi arsitektur perangkat lunak sebelumnya dimana hanya digunakan pada Facebook saja.

Dan perubahannya untuk kebutuhan saat ini adalah penambahan dari versi sebelumnya dengan media sosial Twiter dan Instagram. Dan facebook tetap digunakan sehingga menjadi tiga (3) komunikasi data pada media sosial.

AD 2. Data retrieving engine dikembangkan dengan menggunakan bahasa pemrograman.

$\Rightarrow$ Menurut Feng Chen, Bahasa pemrograman tidak akan berpengaruh terhadap perubahan gaya arsitektur karena merupakan akibat dari suatu pengembangan yang harus menggunakan bahasa pemrograman tersebut.

Namun ketika ada kebutuhan baru yang berpengaruh terhadap arsitektur sistem hingga cenderung sistem tersebut berubah, hal ini akan menjadi sebab terjadinya perubahan terhadap gaya arsitektur perangkat lunak dan berakibat pada keputusan penggunaan teknologi/ bahasa pemrograman tertentu.

AD 3. Dapat melakukan proses data mining dengan konten media sosial

$\Rightarrow$ Hal ini dapat berpengaruh terhadap arsitektur perangkat lunak karena kebutuhan versi arsitektur sebelumnya pada perangkat lunak untuk proses datamining hanya menerapkan metode klasifikasi (komponen classifier dimana pre-classified database akan didefenisikan apabila akan menggunakan metode classification).

Selanjutnya pada kebutuhan perangkat lunak berikutnya terdapat penambahan kebutuhan dari versi sebelumnya dengan metode clustering, sehingga juga akan berdampak pada keputusan arsitektur perangkat lunak.

AD 4. Dapat melakukan analisis menggunakan data relasi (main user dan friend) 
$\Rightarrow$ Graph Measuring, kebutuhan tambahan dari versi sebelumnya untuk memperoleh pengetahuan yang ditampilkan dalam visualisasi graph.

Kebutuhan ini akan menjadi keputusan yang dapat merubah arsitektur perangkat lunak.

AD 5. Dapat melakukan proses text mining media sosial pada data hasil pemrosesan data tekstual

Kebutuhan arsitektur yang diperoleh pada Tabel 3 poin User Stories (US) diatas yang akan berpengaruh terhadap arsitektur (AD) hasilnya diperoleh enam (6) poin yang akan berpengaruh yaitu US 1, US 4, US 5, US 6, US 7, US 8 dan tiga (2) poin yang tidak berpengaruh yaitu US 2 dan US 3 terhadap arsitektur sebelumnya berdasarkan proses pengelompokan yang dilakukan untuk mendapatkan kebutuhan yang penting.

\subsection{Pengujian pada studi kasus}

Hasil yang diharapkan dalam pengujian ini adalah adanya peningkatan tingkat persentase dari kebutuhan yang diperoleh berdasarkan arsitektur dengan kebutuhan pada pengembangan aplikasi data mining. Untuk mendapatkan hasil tersebut dilakukan tahapan sebagai berikut,
1. Data kebutuhan yang diperoleh akan ditampilkan dalam format tabel untuk melihat mana kebutuhan yang diperoleh berdasarkan arsitektur dan kebutuhan aplikasi data mining.

2. Selanjutnya akan dilakukan perhitungan persentasenya.

Yang menjadi ukuran adalah,

a. Persentase kebutuhan aplikasi yang dipakai terhadap kebutuhan yang dihasilkan berdasarkan penelitian ini

b. Persentase kebutuhan aplikasi data mining yang didukung oleh kebutuhan pada penelitian ini.

Untuk pengujian dalam penelitian ini, diambil beberapa aplikasi data mining yang juga sudah pernah dikembangkan sebelumnya untuk melihat seberapa besar requirements yang digunakan. Kasus yang diambil ada 3 aplikasi dan ketiganya merupakan kasus yang sama-sama mengukur tingkat kelulusan mahasiswa dengan menggunakan pendekatan mining dalam penelitian dan penulis yang berbeda. Secara umum telah diperoleh requirements yang ada pada ketiga kasus tersebut, terlampir pada tabel 4 .

Tabel 3.Data kebutuhan

\begin{tabular}{|c|c|c|c|}
\hline $\begin{array}{c}\text { Usulan kebutuhan } \\
\text { perangkat lunak datamining }\end{array}$ & $\begin{array}{c}\text { Kebutuhan } \\
\text { Nuqson [13] }\end{array}$ & $\begin{array}{c}\text { Kebutuhan } \\
\text { Faundry [14] }\end{array}$ & $\begin{array}{l}\text { Kebutuhan } \\
\text { Danny [12] }\end{array}$ \\
\hline $\begin{array}{l}\text { Sistem dapat melakukan koleksi data } \\
\text { dari data sumber tertentu }\end{array}$ & - & - & \\
\hline $\begin{array}{l}\text { Dapat melakukan berbagai teknik } \\
\text { preprocessing data untuk keperluan } \\
\text { proses data mining }\end{array}$ & 1 & $\gamma$ & - \\
\hline $\begin{array}{l}\text { Dapat melakukan proses data mining } \\
\text { dengan menerapkan teknik data } \\
\text { mining tertentu dari data yang sudah } \\
\text { melalui proses seleksi }\end{array}$ & 1 & $\checkmark$ & $\gamma$ \\
\hline $\begin{array}{l}\text { Dapat melakukan analisis } \\
\text { menggunakan data relasi dengan } \\
\text { teknik pengukuran (network metrics) } \\
\text { pada data relasi (main user dan friend) } \\
\text { untuk memperoleh pengetahuan } \\
\text { (influence, important) }\end{array}$ & - & - & - \\
\hline $\begin{array}{l}\text { Dapat melakukan proses text mining } \\
\text { pada data hasil pemrosesan data } \\
\text { tekstual untuk memperoleh } \\
\text { pengetahuan (ex. trending topic, } \\
\text { sentimen analysis) }\end{array}$ & - & - & - \\
\hline Dapat menampilkan output visualisasi & $\checkmark$ & $\checkmark$ & $\checkmark$ \\
\hline- & - & $\begin{array}{l}\text { Aplikasi ini mampu } \\
\text { melakukan pembuatan } \\
\text { laporan berupa laporan } \\
\text { tabel hasil proses mining, } \\
\text { laporan rangkuman, } \\
\text { laporan saran }\end{array}$ & \\
\hline
\end{tabular}




\begin{tabular}{lll}
\hline- & - & Sistem menyediakan \\
& layanan bantuan agar \\
pengguna lebih mudah \\
dalam mengoperasikan \\
program (NFR)
\end{tabular}

Berdasarkan data kebutuhan diatas, diperoleh hasil sebagai berikut :

1. Ada 3 usulan $(50 \%)$ kebutuhan perangkat lunak yang digunakan oleh Nuqson atau dapat juga disimpulkan bahwa semua kebutuhan perangkat lunak Nuqson telah dapat dipenuhi oleh usulan kebutuhan perangkat lunak $(100 \%)$

2. Ada 3 usulan (50\%) kebutuhan perangkat lunak yang digunakan oleh Faundry atau dapat juga disimpulkan bahwa semua kebutuhan perangkat lunak Faundry terdapat 3 diantaranya telah dapat dipenuhi oleh usulan kebutuhan perangkat lunak dan 1 kebutuhan adalah kebutuhan tambahan $(75 \%)$.

3. Ada 3 usulan $(50 \%)$ kebutuhan perangkat lunak yang digunakan oleh Danny atau dapat juga disimpulkan bahwa semua kebutuhan perangkat lunak Danny terdapat 3 diantaranya telah dapat dipenuhi oleh usulan kebutuhan perangkat lunak dan 1 kebutuhan adalah kebutuhan tambahan $(75 \%)$.

Dari tabel 4 diatas diperoleh persentase rata-rata sebesar (50\%) kebutuhan yang digunakan pada aplikasi adalah usulan kebutuhan perangkat lunak datamining. Dan persentase rata-rata sebesar $(83,33 \%)$ kebutuhan aplikasi adalah kebutuhan yang didukung oleh usulan kebutuhan perangkat lunak datamining.

\section{KESIMPULAN DAN SARAN}

\subsection{Kesimpulan}

Dalam penelitian ini dapat ditarik beberapa kesimpulan, sebagai berikut :

1. Kebutuhan arsitektur perangkat lunak datamining sebelumnya dapat digunakan untuk memperoleh kebutuhan, sehingga kebutuhan yang sudah diperoleh akan menjadi usulan untuk pengembangan aplikasi datamining.

2. Usulan kebutuhan perangkat lunak datamining setelah dilakukan pengujian pada beberapa aplikasi datamining memberikan gambaran persentase rata-rata $(50 \%)$ terpenuhi usulan kebutuhan perangkat lunak digunakan pada aplikasi datamining dan persentase rata-rata $(83,33 \%)$ kebutuhan aplikasi datamining didukung oleh usulan kebutuhan perangkat lunak.

\subsection{Saran}

Arsitektur perangkat lunak yang digunakan dalam upaya pembangkitan praktik rekayasa kebutuhan dalam penelitian ini adalah arsitektur perangkat lunak datamining pada kasus media sosial dan diujikan pada kebutuhan aplikasi data mining untuk kebutuhan aplikasi datamining umumnya. Perlu dilakukan penelitian lebih lanjut,

1. Pengaruh usulan kebutuhan perangkat lunak datamining yang diperoleh saat ini dan beberapa kebutuhan tambahan pada aplikasi terhadap arsitektur

2. Pengembangan model arsitektur perangkat lunak datamining terhadap kebutuhan tambahan pada aplikasi

\section{DAFTAR PUSTAKA}

[1] D. Garlan, "The Role Of Software Architecture In Requirements Engineering,” IEEE, P. 240, 1994.

[2] C. Jones, "POSTIVE AND NEGATIVE INNOVATIONS IN SOFTWARE ENGINEERING," International Journal Of Software Science And Computational Intelligence, 2006.

[3] J. Cleland-Huang, A. Czauderna And E. Keenan, "A Persona-Based Approach For Exploring Architecturally Significant Requirements In Agile Projects," Requirements Engineering: Foundation For Software Quality, Pp. 18-33, 2013.

[4] R. S. Wahono, "ANALYZING REQUIREMENTS ENGINEERING PROBLEMS," In Proceedings Of The IECI Japan Workshop 2003, Japan, 2003.

[5] F. Chen, "From Architecture To Requirements : Relating Requirements And Architecture For Better Requirements Engineering," Pp. 451-455, 2014.

[6] L. Bass, P. Clements And R. Kazman, "What Is Software Architecture ?," In Software Architecture In Practice, Addison Wesley, 2003, Pp. 43-46.

[7] G. S. Patton, "Requirements Engineering In The Solution Domain," Requirements Engineering, Springer, Pp. 115136, 2011.

[8] Oracle Data Mining Concepts, Oracle, 2008.

[9] M. A. Russell, Mining The Social Web, O'Reilly, 2011.

[10] A. Perwitasari, Arsitektur Perangkat Lunak Untuk Analisis Data Media Sosial, Bandung: ITB, 2015.

[11] M. M. Rahman, "Mining Social Data To Extract Intellectual Knowledge," International Journal Of Intelligent Systems And Applications, Pp. 15-24, 2012.

[12] D. Himawan, Aplikasi Data Mining Menggunakan Algoritma ID3 Untuk Mengklasifikasi Kelulusan Mahasiswa Pada Universitas Dian Nuswantoro Semarang, Semarang: Universitas Dian Nuswantoro, 2014.

[13] N. M. Huda, APLIKASI DATA MINING UNTUK MENAMPILKAN INFORMASI TINGKAT KELULUSAN MAHASISWA, Semarang: UNIVERSITAS DIPONEGORO, 2010.

[14] F. A. Ma'ruf, APLIKASI DATA MINING UNTUK MENGETAHUI HUBUNGAN PROSES MASUK DENGAN TINGKAT KELULUSAN MAHASISWA, Yogyakarta: STMIK AMIKOM, 2013. 


\section{BIODATA PENULIS}

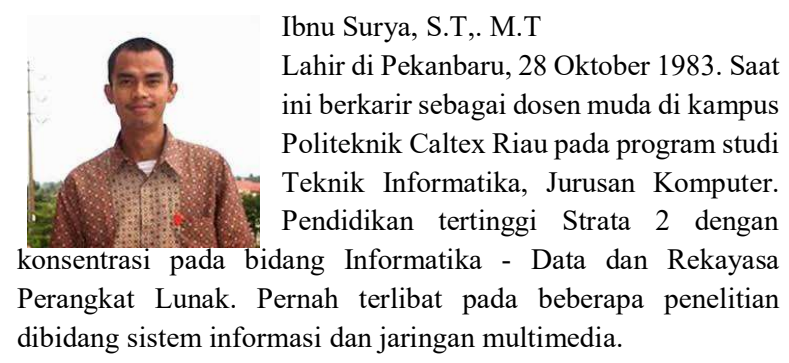

